\title{
Issues of Sharia Debt-Based Crowdfunding on Regulations in Indonesia
}

\author{
Afif Noor $^{1, *}$, Dwi Wulandari ${ }^{2}$, Haniff Ahamat ${ }^{3}$, Ismail Marzuki ${ }^{1}$, Akhmad Arif Junaidi ${ }^{1}$, Mahsun ${ }^{1}$ \\ ${ }^{1}$ Faculty of Sharia and Law, Universitas Islam Negeri Walisongo, Jawa Tengah, Indonesia \\ ${ }^{2}$ Faculty of Humanities, Diponegoro University, Jawa Tengah, Indonesia \\ ${ }^{3}$ Faculty of Law, National University of Malaysia, Selangor, Malaysia
}

Received October 2, 2021; Revised December 23, 2021; Accepted January 22, 2022

\section{Cite This Paper in the following Citation Styles}

(a): [1] Afif Noor, Dwi Wulandari, Haniff Ahamat, Ismail Marzuki, Akhmad Arif Junaidi, Mahsun , "Issues of Sharia Debt-Based Crowdfunding on Regulations in Indonesia", Universal Journal of Accounting and Finance, Vol. 10, No. 1, pp. 298 - 305, 2022. DOI: 10.13189/ujaf.2022.100130.

(b): Afif Noor, Dwi Wulandari, Haniff Ahamat, Ismail Marzuki, Akhmad Arif Junaidi, Mahsun (2022). Issues of Sharia Debt-Based Crowdfunding on Regulations in Indonesia. Universal Journal of Accounting and Finance, 10(1), 298 - 305. DOI: 10.13189/ujaf.2022.100130.

Copyright $\odot 2022$ by authors, all rights reserved. Authors agree that this article remains permanently open access under the terms of the Creative Commons Attribution License 4.0 International License

\begin{abstract}
Sharia debt-based crowdfunding is experiencing good growth in Indonesia. Its existence as a financial service institution based on information technology carries high risks such as default risk, misuse of funds, the potential for shadow banking, personal data misuse, risk of Sharia compliance, and risk of consumer protection and dispute resolution. The purpose of this study is to find issues related to Sharia debt-based crowdfunding as a financial service institution that is subject to Sharia principles in crowdfunding regulations in Indonesia. This research is normative juridical research that uses secondary data as research material, including primary, secondary, and tertiary legal materials. The results show that no regulation specifically regulates Sharia debt-based crowdfunding in Indonesia. Financial Services Authority Regulation number 77/2016 as the legal basis for debt-based crowdfunding in Indonesia does not regulate Sharia debt-based crowdfunding as a financial service institution that is subject to Sharia principles and does not regulate legal protection for its consumers. Sharia debt-based crowdfunding must be regulated to protect consumers, both preventive and repressive protection as a manifestation of the rule of law principle adopted by Indonesia.
\end{abstract}

Keywords Sharia Debt-Based Crowdfunding, Regulation, Sharia Principle, Customer Protection

\section{Introduction}

Sharia debt-based crowdfunding or Islamic debt-based crowdfunding is one type of Islamic law-based crowdfunding that is growing rapidly in Indonesia. In 2020, the distribution of Sharia debt-based crowdfunding grew by $50 \%$ compared to 2019 . Meanwhile on the asset side, in April 2021, total assets reached IDR 109.4 billion or has a market share of $2.57 \%$ of the total assets of the debt-based crowdfunding industry which reached IDR 4.23 trillion with outstanding financing that reached IDR 20.61 trillion [1]. The growth and development of Sharia debt-based crowdfunding in Indonesia cannot be separated from the growth of Islamic fin-tech globally. DinarStandard and Elipses [2] in The Global Islamic Fin-Tech Report 2021 note that in 2020 the total Islamic fin-tech market from 57 member countries of the Organization of Islamic Cooperation will reach US\$ 49 billion. The report places Indonesia in fourth place as a country experiencing rapid development in the field of Islamic fin-tech with a market size of US\$ 2.9 billion and is estimated to reach US\$ 8.3 billion by 2025. Several things are driving the growth of the global Islamic financial economy, including increasing the living standards of the Muslim population, developing national strategies for countries that are dedicated to halal products, and increasing Islamic ethics and values [3].

The development of Islamic fin-tech was also recorded by Islamic Finance News Fin-Tech [4], in a report released in October 2020, globally there have been 147 Sharia 
fin-tech companies consisting of payment, investment and risk management, aggregators, crowdfunding including debt-based crowdfunding, totaling 21 companies. Compared to other types of fin-tech, Sharia crowdfunding is an entity that is expected to experience considerable growth. Geographically, ASEAN is a country that has the opportunity to experience rapid growth compared to other countries in the region with a growth of approximately $39 \%$, while the Middle East is $31 \%$, the UK is $16 \%$, European countries other than the UK are $12 \%$ and North America is 2\% [5]. This data shows that Islamic debt-based crowdfunding is a global phenomenon that continues to grow and develop following economic trends along with the high use of information technology today. In addition, the growth of sharia fintech is also inseparable from the existence of Muslim consumers and religious communities who are aware of financial technology and want to do it according to their beliefs.

In the ASEAN region, Indonesia is the country with the largest number of Muslims, which reached $86.88 \%$ or 236.53 million Muslims out of a total population of 272.23 million people [6], making Islamic debt-based crowdfunding develop well. The Financial Services Authority noted that in June 2021 [7], five Sharia debt-based crowdfunding platforms have been operated, and five Sharia debt-based crowdfunding platforms have registered status, so that in total there are ten Sharia debt-based crowdfunding service providers in Indonesia. This data increased by $400 \%$ compared to 2018 which only amounted to 2 companies. In terms of disbursement of loan funds, at the end of 2020, it reached IDR 1.7 trillion, an increase of 70\% compared to the previous year period [8]. Meanwhile, in terms of assets, in April 2021 total assets reached IDR 109.4 billion or has a market share of $2.57 \%$ of all fin-tech lending industry assets that reached IDR 4.23 trillion with outstanding financing of IDR 20.61 trillion [9]. The data only comes from Sharia debt-based crowdfunding platforms that have registered or licensed status, because several Sharia debt-based crowdfunding platforms are illegal because they are not registered or obtained permission from the Financial Services Authority.

The data shows that Sharia debt-based crowdfunding is growing rapidly but has risks that threaten its development and growth, such as the risk of default, misuse of funds, misuse of personal data, the potential for shadow banking, risk of sharia compliance, and risk of consumer protection and dispute resolution. Efforts to reduce risk in Sharia debt-based crowdfunding policymakers must create a harmonious atmosphere and build an Islamic crowdfunding ecosystem consisting of a comprehensive regulatory framework and a legal culture of society supported by adequate technological infrastructure [10]. Regulation and understanding of community law are very important to realize justice, benefit, and legal certainty. This study will examine crowdfunding regulations in Indonesia to find issues related to the existence of Sharia debt-based crowdfunding. This research is motivated by
Hendratmi, et al. [11] whose research concludes that regulators must formulate regulations and laws governing crowdfunding companies to operate properly and recommends that further research be conducted to review existing regulations and propose new regulations related to crowdfunding.

\section{Materials and Methods}

This research is qualitative research that makes law the object of study and is known as normative juridical research. This study examines regulations related to Sharia debt-based crowdfunding. The data used is secondary data obtained through library research in the form of primary legal materials, namely laws and regulations, secondary legal materials in the form of scientific works contained in books, journals, and so on, as well as tertiary legal materials. The data obtained was systematized and processed for in-depth analysis using descriptive analysis.

\section{Results and Discussion}

Sharia debt-based crowdfunding is a crowdfunding activity based on Sharia law or Islamic principles. In general, crowdfunding is a fundraising platform for a specific project or company that uses Internet technology from potential donors. Funk [12] categorizes crowdfunding into four types; a) donation-based crowdfunding; crowdfunder will not receive any refund at all. The funds generated by the donation-based crowdfunding platform are used for social activities, education, health, and creative industry development. b) Reward-based crowdfunding; crowdfunders receive tangible or intangible rewards or compensation for their financial contributions to a particular project or business. The owner of the project or company makes an offer in the form of a gift or other form of certain goods, services, or rights, and it is not possible to estimate the results or benefits derived from the project or company being funded. c) debt-based crowdfunding; This crowdfunding, also known as crowd-lending, is a type of crowdfunding that is based on debt or loans. The fundraiser or borrower must repay the loan with or without additional interest. However, in general, fundraisers or borrowers need to pay interest and must pay fees to the relevant platform. d) Stock-based crowdfunding; crowdfunding investors as investors who obtain shares or equity as part of the company's ownership, and are entitled to receive rewards in the form of dividends.

Sharia debt-based crowdfunding is part of Sharia economic activities. Mujahidin [13] is of the opinion that in the perspective of Sharia economics, institutions or companies that apply Sharia principles must pay attention to two things; 1) Guarantee of compliance with Sharia law; Sharia principles must be a guideline in making contracts and complying with obligations, reporting all transactions 
according to Sharia accounting standards, work environment, and culture and financing that adheres to Sharia principles. 2) Consumer protection as a form of worldly and hereafter balance in seeking sustenance and carrying out religious orders that require seeking halal sustenance. Therefore, Sharia compliance is an important thing that must be achieved and makes it different from traditional financial technology.

Based on this opinion, the study of Sharia debt-based crowdfunding in crowdfunding regulation in Indonesia will focus on two main issues, namely Sharia principles as the operational basis for Sharia debt-based crowdfunding and consumer protection for Sharia debt-based crowdfunding in crowdfunding regulations. Both will be explained in the discussion below.

\subsection{Issues of Sharia Principles in Debt-Based Crowdfunding Regulations}

The existence of Sharia debt-based crowdfunding as a form of Sharia economic activity based on Sharia principles requires it to uphold the principles of public benefit and the principle of justice. The parties involved in Sharia debt-based crowdfunding business activities must uphold ethics and norms in economic activities. There are three characteristics of such norms used in implementing the principles of Islamic law or Sharia principles, namely the principle of justice, avoiding prohibited activities and paying attention to aspects of benefit [14]. These three principles are oriented towards the creation of a balanced economic activity and the fulfillment of Sharia principles.

There are several notions of sharia principles, one of which is stated by Nafis [15] that sharia principles are principles of Islamic law in economic activities that do not contain gambling, fraud, usury, persecution, bribery, illicit goods, and immorality. Meanwhile, in Law Number $10 / 1998$ concerning Banking, it is stated that the principle of Sharia is a rule of agreement based on Islamic law between a bank and other parties to save funds and or finance business activities or other activities that are declared under Sharia. In contrast to the understanding of Sharia principles in the banking law, Law Number 21/2008 concerning Sharia Banking states that Sharia principles are principles of Islamic law in banking activities based on fatwas issued by institutions that have the authority to determine fatwas. In the field of Sharia. Hamid [16] provides an understanding that the Sharia principles are all provisions of the Islamic law that regulate human relations with Allah SWT (vertical) and the relationship between humans and their neighbors and their environment (horizontally). According to him, the term Sharia is more nuanced in law related to Islamic economic activities. Apart from differences of opinion in interpreting the notion of Sharia principles, Sharia principles remain the basis for Sharia debt-based crowdfunding in carrying out business activities.

Based on this understanding, Sharia principles are principles that are used as guidelines in economic activities both sourced from Islamic law and determined by institutions that have the authority to establish the law. Thus, acts or actions that are prohibited in Islamic law may not be carried out in carrying out economic activities, such as usury, uncertainty, speculation, hiding defects, harming others, and something that is forbidden. The agreement that forms the basis for the legal relationship of Sharia economic actors must also be based on the principles of balance, fairness, and in accordance with Islamic law and applicable laws and regulations. These agreements include al-Bai', Ijarah, Mudharabah, Musyarakah, Wakalah bi al-Ujrah, Qardh, and other agreements stipulated by Islamic law and institutions authorized to establish the law. These Sharia principles must be applied in Sharia debt-based crowdfunding as part of Sharia economic activities.

However, Sharia principles will not be implemented properly in Sharia debt-based crowdfunding if no regulation has coercive power so that every Sharia debt-based crowdfunding platform applies Sharia principles in its operations. Therefore, a regulation that regulates Sharia debt-based crowdfunding is needed. The importance of Sharia debt-based crowdfunding arrangements is based on the idea that Indonesia is a state of law. Law is the holder of control in the life of the nation and state. The state and law are one unit as stated by Soehino [17] by quoting the opinion of Hans Kelsen that the state is a legal order that arises because of the creation of legal regulations that determine how individuals in society or the state must be held accountable for their actions. This legal regulation is binding. If it is not complied with, it can be subject to sanctions. In other words, the state is a coercive legal order, because of its coercive nature, in the state, there is a right to rule and an obligation to submit. Thus, the state is synonymous with law. The existing law must provide legal certainty for the parties involved in these economic activities. Husen [18], citing Scheltema, also emphasized that legal certainty is a feature of a rule of law. According to him, every state of law must be based on four main principles, namely the principle of legal certainty, equality, democracy, and services to the community carried out by the government.

So far, the existence of Sharia debt-based crowdfunding as a business entity that is subject to Sharia principles is not regulated in regulations or other laws and regulations. The Financial Services Authority Regulation Number 77/2016 concerning Information Technology-Based Lending and Borrowing Services does not mention the existence of Sharia debt-based crowdfunding at all. Several things show that the Financial Services Authority Regulation Number 77/2016 does not regulate Sharia debt-based crowdfunding [19];

(a) The legal relationship between the crowdfunding platform and lenders and borrowers is based on an interesting system that connotes usury. In Islamic law, transactions that contain elements of usury are 
prohibited, as well as in Sharia debt-based crowdfunding;

(b) This Financial Services Authority Regulation uses the term "borrowing money" which is the same as Qardh term in Islamic law. Islam stipulates that there should not be any addition to the Qardh contract, meaning that the Qardh cannot be used in a business relationship because business people are prohibited from taking advantage of the use of the contract;

(c) The regulation of the Financial Services Authority also does not stipulate a Sharia supervisory board that oversees sharia debt-based crowdfunding business activities. The Limited Liability Company Law mandates that every company that carries out business activities based on Sharia principles must have a Sharia supervisory board.

Sharia debt-based crowdfunding regulations are integrated with conventional debt-based crowdfunding regulations. Though both have different philosophies and operations. The differences between the two include:

(a) Borrowers are charged with interest, the amount of which is determined by conventional crowdfunding platforms, while in Sharia debt-based crowdfunding, the lender's profits depend on the type of contract used. If using an Ijarah contract, the lender gets an Ujrah. If using a Mudharabah contract, the lender will get a profit-sharing percentage agreed upon by the parties;

(b) Regarding risk, in conventional debt-based crowdfunding the responsibility of the borrower is entirely, but this does not apply to Sharia debt-based crowdfunding. When using Mudharabah and Musyarakah contracts, the risk is the responsibility of both parties involved in the contract.

(c) Money is a commodity lent by conventional platforms to borrowers. Meanwhile, in the Sharia debt-based crowdfunding platform, there is no money loan. The platform only provides goods or services, and no cash loans.

As part of an Islamic financial institution, Sharia debt-based crowdfunding faces risks that are not faced by conventional financial institutions, namely the risk of Sharia compliance [20]. To minimize this risk, a Sharia supervisory board is needed to carry out the function as a Sharia supervisor with the main task of ensuring that Sharia principles are used as a foothold in producing service products and all Sharia debt-based crowdfunding activities. Hafiduddin and Tanjung [21] argue that in the Islamic perspective there are two kinds of supervision, namely internal supervision that comes from the belief of a Muslim, all his actions are always supervised and accounted for before Allah SWT, and external supervision in the form of institutional supervision. This supervision is accompanied by planning and completion.

Internal supervision is attached to individuals involved in Sharia debt-based crowdfunding. This supervision will depend on his adherence to religious teachings. Meanwhile, external supervision is carried out by the leader directly and indirectly. Direct supervising involves the participation of the community in the supervision of the operations of Sharia debt-based crowdfunding, while indirect supervision is through the establishment of laws and regulations. Establishment regulations that contain Sharia supervision on Sharia debt-based crowdfunding accord with the 1945 Constitution that stipulates that Indonesia is a state of law.

The regulation will provide legal certainty, justice, and benefit for all parties. Although there has been a fatwa from the Indonesian Council of Ulama Number 117/DSN-MUI/II/2018 concerning Information Technology -Based Financing Services Based on Sharia Principles, this fatwa has no legal force because there are no regulations that stipulate that crowdfunding based on Sharia debt must comply with the fatwa. In contrast to Islamic banks, which are required to comply with any fatwa qualified by the Indonesian Council of Ulama, Article 1 (12) states that the Sharia principles applicable to Islamic banks are Sharia principles established by the Indonesian Council of Ulama [22].

Friedman [23] argues that in the legal system three elements are closely related, namely legal substance, legal structure/legal institution, and legal culture. In Friedman's view, the structure is a framework that forms and limits the whole. In the legal system, these structures are law enforcement agencies, including the judiciary. The substance or legal material is the rules, norms, and patterns of community behavior. The substance includes the living law (the law that lives in society) and is not only defined as the rules contained in the legislation or law in the book. Meanwhile, legal culture is a human attitude towards the law as well as the legal system, values, beliefs, and thoughts. Legal culture can also include the atmosphere of social thought and social forces that determine how the law is used, avoided, and abused. Therefore, regulation of Sharia debt-based crowdfunding is very important to improve the implementation of Sharia principles and create legal order because basically regulation has three main functions [24], namely:

(1) Means of order or code of ethics; regulations serve as guidelines in the social dynamics of society, both formal and informal;

(2) Development instruments; regulations can be used as a means to mobilize resources so that predetermined goals can be achieved;

(3) Integration factor; regulations can unify fields and policies in state administration into the national regulatory system.

Based on this assumption, regulation or rule of law is a means to achieve the idealized goal to improve general welfare as a welfare state. The goal to be achieved is the realization of a just and prosperous society both spiritually 
and materially based on Pancasila and the 1945 Constitution.

\subsection{Issues of Consumer Protection in Debt-based Crowdfunding Regulations}

In English, there are two terms related to the mention of people/entities who use goods/services, namely customer and consumer. Customers are consumers who have consumed a product produced by a producer/business actor. While consumers are all people or society including customers [25]. Meanwhile, in Law Number 8/1999 concerning Consumer Protection, it is stated that a consumer is anyone who uses goods or services provided by the community, either for the benefit of himself, his family or the interests of other people and the interests of other living creatures with no intention of being traded. Based on this understanding, consumers are people or legal entities that use goods or services for their use or other people, including other living things

Consumer protection is inherent in all business activities carried out by business actors and their consumers. In the financial services sector, the International Financial Corporation defines financial consumer protection as any activity, action, or set of rules that seek to reduce the risk and harm to consumers associated with the use of financial products, services, or relationships with Financial Service Providers [26].

Consumer protection in the era of information technology which almost dominates all aspects of human life must be realized by policymakers and paid attention to by business actors in the financial services sector as part of economic activity. There are reasons to explain the need for consumer legal protection in economic activities [27]; a) Consumer protection is the same as the protection of citizens required by the Preamble to the 1945 Constitution, b) needed to prevent consumers from being negatively affected by the use of technology, c) needed to ensure the sustainability of sources of development funds from consumers. To protect consumers in this digital era, the G20/OECD [28] has established several basic principles in consumer protection as outlined in the Policy Guidance on Financial Consumer Protection Approaches in the Digital Age. The basic principles of consumer protection include:

(1) Regulatory and supervisory legal framework; The law should include consumer protection as an integral part that reflects national and global diversity. To protect consumers from financial fraud, abuse and misconduct, there must be strong and effective legal and judicial, or supervisory mechanisms accompanied by deterrent sanctions. The existence of financial service providers and their authorized agents must be properly regulated and/or monitored, taking into account relevant services and approaches to specific sectors;

(2) Supervisory body; protecting consumer interests requires a supervisory body that is explicitly responsible for the protection of financial consumers with appropriate, independent, accountable, capable, transparent, and adequate responsibilities and governance. Regulatory bodies must maintain consumer confidentiality, proprietary information and avoid conflicts of interest under high professional standards;

(3) Justice; Financial consumers must receive fair and honest treatment at all stages of their legal relationship. Such treatment should be an integral part of good governance and corporate culture;

(4) Transparency; Financial service providers and their authorized agents must provide consumers with information about the benefits, risks, and conditions of the product. In particular, it must also provide information about the material aspects of financial products. All financial promotional materials must be accurate, honest, understandable, and not misleading;

(5) Education; all stakeholders in financial institutions should promote financial education and awareness. Rights and responsibilities must be easily accessible by consumers. Appropriate mechanisms must be developed to help consumers gain knowledge, skills, and confidence to properly understand risks, including financial risks and opportunities, make informed choices, know where to go for help, and take effective actions that can improve their financial well-being alone;

(6) Asset protection; consumers must obtain information on control mechanisms and certainty of proper protection of asset security; deposits, savings, and or other assets from fraud or other abuse;

(7) Personal data protection; there must be control mechanisms that protect consumers' personal information and data. The mechanism must contain the purpose of collecting, processing, storing, using, and disclosing the consumer's data. The mechanism must also recognize the right of consumers to obtain information about sharing data, accessing data, and obtaining immediate correction and/or deletion of data that is inaccurate, or data that is illegally collected or processed;

(8) Handling complaints and anti-losses; power holders must ensure that consumers have access to adequate complaint handling and redress mechanisms that are accessible, affordable, independent, fair, accountable, timely, and cost-efficient without imposing unreasonable costs, delays, or burdens on consumers. Financial service providers and authorized agents should have a complaint handling and redress mechanism. In addition, there must also be an institution that handles efficient independent compensation settlements;

(9) The principle of competition; open competition nationally and internationally so that consumers have many choices in using financial services. Healthy competition is expected to create competitive 
pressure on providers to offer competitive products, increase innovation and maintain high service quality. Consumers should be able to search, compare and, where appropriate, switch between products and providers with ease and at reasonable and transparent costs.

The principle of consumer protection can be formulated in five basic principles of consumer protection in financial service institutions, namely the principle of transparency, the principle of balanced treatment, confidentiality and security of consumer personal data, and the principle of resolving consumer complaints and disputes that are simple, fast and low cost. These basic principles must be contained in the regulation of debt-based crowdfunding to create legal certainty and order because regulation has the main function as a means to create order and serves as a development tool to monitor and mobilize resources to achieve predetermined goals.

Currently, there are several regulations related to consumer protection in the financial services industry; Law Number 8/1999 concerning Consumer Protection, Regulation of the Financial Services Authority of the Republic of Indonesia Number 31/2020 concerning the Implementation of Consumer Services, Regulation of the Financial Services Authority of the Republic of Indonesia Number 18/2018 concerning Consumer Complaints in the Financial Services Sector Consumer Services and Authority Circulars Financial Services of the Republic of Indonesia Number 2/2014 concerning Services and Settlement of Consumer Complaints Against Financial Services Companies. However, these laws and regulations fail to protect consumers of Sharia debt-based crowdfunding because they do not regulate Sharia debt-based crowdfunding and do not place the Sharia debt-based crowdfunding platform as a party that can be held accountable for the possible risks posed by their mistakes and negligence due to their status only as a service provider, not as a business actor.

In addition to the absence of adequate legal regulations, the lack of consumer protection against Sharia debt-based crowdfunding is also caused by weak law enforcement against illegal crowdfunding platforms. The Financial Services Authority feels it is not authorized to take action on illegal Sharia debt-based crowdfunding platforms because in substance Financial Services Authority Regulation Number 77/2016 only regulates and binds Sharia debt-based crowdfunding platforms that are licensed or registered with the Financial Services Authority. Thus, consumers or users of illegal Sharia debt-based crowdfunding services are very vulnerable to being harmed, especially concerning personal data that is misused by the platform. This condition is partly because the public is not well literate to choose and use a licensed or registered Sharia debt-based crowdfunding platform.

The Financial Services Authority Regulation Number 77/2016 categorize crowdfunding platforms including the
Sharia debt-based crowdfunding platform as other financial service institutions and are not categorized as business actors but are only categorized as start-ups with limited liability companies and cooperatives. Ideally, every business entity that runs a business is categorized as a business actor, especially a limited liability company whose status is a legal entity. Platform status that is not categorized as a business actor will harm consumers because the platform can avoid the obligation to be responsible for all actions that harm consumers. After all, in the consumer protection law, the relationship between service providers and service users is called business actors and consumers. Crowdfunding regulations also do not limit how much a crowdfunding platform can determine the number of fees it can earn from users of the services it provides. In practice, the determination of the fee amount is carried out by Asosiasi Fintech Pendanaan Bersama as the only financial technology platform association that has received a determination from the Financial Services Authority and this provision only binds debt-based crowdfunding platforms including Sharia debt-based crowdfunding with registered or licensed status from the Financial Services Authority. As a result, many consumers are entangled with high interest and fees which are mainly carried out by illegal platforms.

Weak consumer protection for Sharia debt-based crowdfunding is also demonstrated by crowdfunding regulations that do not require debt-based crowdfunding platforms, both conventional and Sharia, to ensure every loaned fund. No institution guarantees the security of lender funds. Whereas crowdfunding is a high-risk business activity, it has the potential to harm consumers, especially the security of lender funds. In addition, consumers often receive threats and intimidation from illegal platforms that collect in ways that violate the law and ethics. Consumers often get intimidation or threats of spreading consumer personal data, disseminating existing data on consumer telecommunication facilities whose permission to access consumer data has been given at the time of applying for loans [29]. This is exacerbated by the absence of a personal data protection law so that the debt-based crowdfunding platform is very flexible in using consumer personal data.

\section{Conclusion}

Based on the research, it is found that Sharia debt-based crowdfunding is not regulated on debt-based crowdfunding regulation in Indonesia. There is no regulation of Sharia principles as the operational basis for Sharia debt-based crowdfunding and there is no provision that regulates consumer protection for Sharia debt-based crowdfunding. Therefore, joint efforts are needed between the government and authorities in the financial services industry as well as crowdfunding practitioners, especially Sharia debt-based crowdfunding service providers to jointly create a 
conducive climate following their respective roles so that Sharia debt-based crowdfunding can grow better again and consumers get good protection. The government and financial service authorities must make regulations that regulate Sharia debt-based crowdfunding to realize legal certainty, justice, and benefit as legal objectives under the principles of the rule of law adopted by Indonesia.

\section{Acknowledgements}

Thank you to the Institute of Research and Community Services, Universitas Islam Negeri Walisongo, Semarang for the financial assistance provided through The State Higher Education Operational Costs (BOPTN) 2021.

\section{REFERENCES}

[1] P. Ardianto, "Fintech Lending Syari’ah Tumbuh 50\% di tahun 2020”. Online available from https://investor.id/finan ce/fintech-lending-syariah-tumbuh-50-di-2020, accessed on 19 July 2021.

[2] DinarStandar and Elipses, Global Islamic Fintech Report 2021”, London: DinarStandard and Elipses, online available from https://cdn.salaamgateway.com/reports/pdf/ 6127a0965 afd7898a34f69dadc24b8d17ada0b1b.pdf, accessed on July 19, 2021.

[3] DinarSTandard, "State of The Global Islamic Economy Report Driving The Islamic Economy Revolution 4.0 2019-2020”, DinarStandard, New York, online available from

https:/smartmuslim.co.ke/wp-content/uploads/2019/11/sta te-of-global-islamic-economy-report-2019-20.pdf, accessed on July 19, 2021.

[4] Islamic Finance News, "IFN Fintech Islamic Landscape", online available from https://www.islamicfinancenews.co m/, accessed on July 19, 2021.

[5] Elipses, “The Global Islamic Fintech Report 2019”, Elipses London, online available fromhttps://ceif.iba.edu.pk/pdf/Is lamicFinTechReport19.pdf, accessed on July 19, 2021.

[6] V. B. Kusnandar, "Sebanyak 86,88\% Penduduk Indonesia Beragama Islam”, online available from https://databoks.k atadata.co.id/datapublish/2021/09/30/sebanyak-8688-pend uduk-indonesia-beragama-islam, accessed on July 20, 2021.

[7] Otoritas Jasa Keuangan, "Perusahaan Fintech Berizin dan Terdaftar di OJK per Juni 2021”, online available from https://www.ojk.go.id/id/kanal/iknb/financial-technology/ Documents/PERUSAHAAN\%20FINTECH\%20LENDIN G\%20BERIZIN\%20DAN\%20TERDAFTAR\%20DI\%20O JK\%20PER\%2010\%20JUNI\%202021.pdf, accessed on July 20, 2021.

[8] F. Sari, "Pinjaman Fintech Syari’ah Capai Rp. 1,7 triliun Pada Tahun 2020”, online available from https://keuangan. kontan.co.id/news/pinjaman-fintechsyariah-capai-rp-17-tril iun-pada-tahun-2020, accessed on July 22, 2021.
[9] P. Ardianto, "Fintech Lending Syari'ah Tumbuh 50\% di tahun 2020”, online available from https://investor.id/finan ce/fintech-lending-syariah-tumbuh-50-di-2020, accessed on July 22, 2021.

[10] F.S. Raden Roro, "The Risk Mitigation to the Islamic Crowdfunding in Indonesia”, in Proceedings of the International Law Conference (iN-LAC 2018) - Law, Technology and the Imperative of Change in the $21^{\text {st }}$ Century, 237-245, 2018, online available from https://www.scitepress.org/Papers/2018/100520/100520.pd f, accessed on July 28, 2021.

[11] Hendratmi, P.S. Sukmaningrum, M.N.H. Ryandono, T.R. Ratnasari, "The Role of Islamic Crowdfunding Mechanism in Business and Business Development”, Journal of Business and Economics Review, Vol. 4, No. 1, 10-23, 2019, online available from http://gatrenterprise.com/GAT RJournals/pdf_files/JBER\%20Vol\%204(1)/2.Achsania\%2 0Hendratmi.pdf, accessed on August 20, 2021.

[12] A.S. Funk, "Crowdfunding in China A New Institutional Economics Approach”, Springer, Cham, 2019.

[13] Mujahidin, "Peluang dan Tantangan Islamic Technology Finance di Indonesia”, 2019, online available from https://mpra.ub.uni-muenchen.de/94842/, accessed on August 20, 2021.

[14] T. Handayani, M.A. Fathoni, "Buku Ajar Manajemen Pemasaran Islam”, Deepublish, Yogyakarta, 2019.

[15] M.C. Nafis, “Teori Hukum Ekonomi Syari’ah: Kajian Komprehensif tentang Teori Hukum Ekonomi Islam Penerapannya Dalam Fatwa DSN dan Penyerapannya Dalam Peraturan Perundang-Undangan”, UI Press, Jakarta, 2011.

[16] Hamid, "Hukum Ekonomi Islam (Ekonomi Syari’ah) Di Indonesia Aplikasi dan Prospektifnya”, Ghalia Indonesia, Jakarta, 2007.

[17] Soehino, “Ilmu Negara”, Liberty, Yogyakarta, 1993.

[18] L.O. Husen, "Negara Hukum, Demokrasi dan Pemisahan Kekuasaan, Social Politic Genius, Makassar, 2019.

[19] A. Noor, H. Ahamat, I. Marzuki, D. Wulandari, A. A. Junaidi, E. Lisdiyono, B. Trisnawati, "Regulation and Consumer Protection of Fintech in Indonesia: The Case of Islamic Fintech Lending”, Linguistics and Culture Review, Vol., 6 No. S3, 49-63, December 2021. https://doi.org/10.21744/lingcure.v6nS3.1938

[20] R. Hassan, "Shariah Non-Compliance Risk and Its Effects on Islamic Financial Institutions”, Shajarah: Journal of the International Institute of Islamic Thought and Civilization (ISTAC), Vol., 21, No. 3, 21-25, December 2016. https://journals.iium.edu.my/shajarah/index.php/shaj/articl e/view/411.

[21] D. Hafiduddin, H. Tanjung, "Manajemen Syari'ah Dalam Praktek, GIP, Jakarta, 2003.

[22] A. Noor, D. Wulandari, "Inconsistency of Guarantee Norms on The Mudharabah Fatwas in Indonesia, International Journal of Multicultural and Multireligious Understanding, Vol. 8, Issue 12, 144-152, December 2021. https://ijmmu.C om/index.php/ijmmu/article/view/3197

[23] L.M. Friedman, "The Legal System a Social Science Perspective”, Russel Sage Foundations, New York, 1979. 
[24] D. Sadiawati (Eds), "Strategi Nasional Reformasi Regulasi Mewujudkan Regulasi Yang Sederhana dan Tertib”, Kementerian Perencanaan Pembangunan Nasional/Bappen as RI, Jakarta, 2015.

[25] Atsar, Apriani, “Hukum Perlindungan Konsumen”, Deepublish, Yogyakarta, 2019.

[26] International Financial Corporation, "Promoting Financial Consumer Protection in Cambodia”, 2015, online available from https://www.ifc.org/wps/wcm/connect/f7125568-e34 1-4b54-abcd-b730c816b60c/Cambodia+Financial+Consu mer+protection-Final.pdf?MOD=AJPERES\&CVID=lKva GMi, accessed on September 15, 2021.
[27] J. Sidabalok, "Hukum Perlindungan Konsumen di Indonesia”, Citra Aditya Bakti, Bandung, 2010.

[28] Organization for Economic Co-Operation and Development G20/OECD, "Policy Guidance on Financial Consumer Protection Approaches in the Digital Age, 2018, online available fromhttps://www.oecd.org/finance/G20-O ECD-Policy-Guidance-Financial-Consumer-Protection-Di gital-Age-2018.pdf, accessed on September 15, 2021.

[29] A. Noor, D. Wulandari, "Landasan Konstitusional Perlindungan Data Pribadi Pada Transaksi Fintech Lending di Indonesia”, Jurnal Ilmiah Dunia Hukum, Vol. 5 No. 2, 99-110, April 2021. http://jurnal.untagsmg.ac.id/ind ex.php/ duniahukum/article/view/1993. 